\title{
Genetic Analysis of Photoperiod Response in Wheat and Its Relation with the Earliness of Heading in the Southwestern Part of Japan
}

\author{
Masahiko Tanio*1), Kenji Kato ${ }^{2)}$, Naoyuki Ishikawa ${ }^{3)}$, Yasuaki Tamura' ${ }^{1)}$, Mitsunori Sato ${ }^{1)}$, \\ Hiroko Takagi') and Makoto Matsuoka ${ }^{1)}$ \\ 1) Okinawa Subtropical Station, Japan International Research Center for Agricultural Sciences, 1091-1 Maezato-Kawarabaru, Ishigaki, \\ Okinawa 907-0002, Japan \\ 2) Okayama University, 1-1-1 Tsushima-Naka, Okayama, Okayama 700-8530, Japan \\ 3) National Agricultural Research Center for the Western Region, 6-12-1 Nishifukatsu, Fukuyama, Hiroshima 721-8514, Japan
}

\begin{abstract}
Genetic analysis of vernalization and photoperiod responses was carried out using eight wheat cultivars, in order to investigate the relationship between their genotype and the earliness of heading in the southwestern part of Japan. Allelism test of the genes for the vernalization response showed that three wheat cultivars, 'Fukuwasekomugi', 'Zenkoujikomugi' and 'Schomburgk', harboured Vrn-D1, Vrn-D1 and Vrn-A1, respectively. Among the eight cultivars tested, 'Haruhikari' was sensitive to short photoperiod, while the others were insensitive. Segregation analysis of the photoperiod response in the $F_{2}$ and $B_{1} F_{1}$ populations showed that the very late heading cultivar 'Haruhikari' did not harbour major genes for insensitivity to photoperiod. Six cultivars characterized by medium to late heading, 'Norin 61', 'Zenkoujikomugi', 'Saitama 27', 'Schomburgk', 'Norin 59' and 'Norin 67', carried a single gene for insensitivity, $P p d-S$, in common. The extremely early heading cultivar 'Fukuwasekomugi' was found to carry two genes for insensitivity, $P p d-S$ and $P p d-F$, the latter displaying a stronger effect for insensitivity to photoperiod. The present study revealed that the earliness of heading in the southwestern part of Japan was closely related to the Ppd genotype of wheat cultivars, whereas it was independent of the Vrn genotype.
\end{abstract}

Key Words: wheat, vernalization response, photoperiod response, genetic analysis, earliness of heading.

\section{Introduction}

Earliness of heading is one of the most important traits for wheat breeding, and cultivars with early heading have been bred in the southwestern part of Japan to be harvested before monsoonal rain. According to Yasuda and Shimoyama (1965), three physiological characters, vernalization response, photoperiod response and earliness per se (originally designated as narrow-sense earliness), are responsible for the earliness of heading, and the photoperiod response is most important in the southwestern part of Japan. Kato and Yamashita (1991) and Fujita et al. (1995) reported that heading time of wheat in the southwestern part of Japan was independent of the genotype for vernalization response. Therefore, early heading cultivars with a winter growth habit, such as 'Iwainodaichi' (Taya et al. 2003), had been successfully bred to avoid frost injury in the southwestern part of Japan. However, the relationship between the genotype for the photoperiod response and heading time of wheat in the southwestern part of Japan remains to be investigated.

The major genes for vernalization insensitivity that

Communicated by Y. Furuta

Received January 24, 2005. Accepted March 9, 2005.

*Corresponding author (e-mail: tanio@affrc.go.jp) convert winter wheat into spring wheat are $V r n-A 1$ (formerly Vrn1), Vrn-B1 (Vrn2), Vrn-D1 (Vrn3), Vrn-D5 (Vrn4) and Vrn-B4 (Vrn5) (Pugsley 1972, Law et al. 1976, Kato et al. 1993, Snape et al. 2001, Iwaki et al. 2002, Kato et al. 2003). The photoperiod response is controlled by three major genes, $P p d-A 1$ (formerly Ppd3), Ppd-B1 (Ppd2) and Ppd-D1 $(P p d 1)$, which induce wheat insensitivity to daylength (Welsh et al. 1973, Keim et al. 1973, Pirasteh and Welsh 1975, Scarth and Law 1983, Scarth and Law 1984, Snape et al. 2001). QTL analysis revealed that additional genetic factors for the photoperiod response are located on chromosome 4B (Sourdille et al. 2000), on chromosomes 4B, 5A, 5B, 7A, and 7B (Shindo et al. 2003) and on chromosomes 5A and 7D (Hanocq et al. 2004). Genetic analysis of the Japanese wheat cultivars has been carried out for the vernalization response, and most of the Japanese cultivars tested were found to carry Vrn-D1 (Gotoh 1979, Iwaki et al. 2000). On the other hand, while the Japanese wheat cultivars with extremely early heading are essentially highly insensitive to short photoperiod (Yoshida et al. 1983), the Ppd genotype has not been identified in any Japanese wheat cultivars or lines.

In the present study, we analyzed the genotype for the response to vernalization and photoperiod in seven Japanese and one Australian wheat cultivars, and investigated the 
relationship between the genotype for vernalization and photoperiod responses and the earliness of heading in the southwestern part of Japan.

\section{Materials and Methods}

\section{Plant materials}

Eight wheat cultivars analyzed in this study were selected, based mainly on their heading traits (Table 1). The seeds of eight cultivars were supplied by the National Institute of Agrobiological Sciences. For the genetic analysis of the vernalization and photoperiod responses, seeds were pregerminated and sown in containers filled with a mix of sterilized soil containing adequate amounts of chemical fertilizer and vermiculite $(1: 1)$ at $3 \mathrm{~cm} \times 3 \mathrm{~cm}$ intervals (130 seeds per container).

\section{Genetic analysis of vernalization response}

Vrn genotype of three cultivars, 'Norin 61', 'Saitama 27 ' and 'Haruhikari', has been identified by Gotoh (1979) (Table 1). Therefore, the Vrn genotype of the other three cultivars with spring growth habit, 'Fukuwasekomugi', 'Zenkoujikomugi' and 'Schomburgk', was analyzed. $\mathrm{F}_{1}$ and $\mathrm{F}_{2}$ populations of crosses between these three cultivars and five tester lines, 'Saitama 27' (Vrn-A1), 'Triple Dirk (B)' ('TD(B)', Vrn-B1), 'TD(E)' (Vrn-D1), 'TD(F)' (Vrn-D5) and 'Norin 59' (winter type), were grown in a glasshouse, with parental lines, at $20^{\circ} \mathrm{C}$ under a 24 hour photoperiod in which natural daylength was extended by the use of incandescent light. The same populations of equal size were vernalized at $5^{\circ} \mathrm{C}$ under continuous illumination of fluorescent light for 70 days and then grown at $20^{\circ} \mathrm{C}$ under a 24 hour photoperiod. Vernalization treatment was started when the first leaf emerged from the coleoptile. The number of days from sowing or after vernalization treatment to heading of the main culm was recorded on a single plant basis. The seeds of three near-isogenic lines, 'TD(B)', 'TD(E)' and 'TD(F)' developed by Pugsley (1972), were provided by the National Agricultural Research Center for the Tohoku Region.

\section{Genetic analysis of photoperiod response}

The $F_{1}, F_{2}$ and $B_{1} F_{1}$ populations of the crosses between a photoperiod-sensitive cultivar 'Haruhikari' and seven insensitive cultivars were vernalized, with their parental lines, at $5^{\circ} \mathrm{C}$ under 8 hour illumination of fluorescent light for 70 days, and then grown in a glasshouse at $20^{\circ} \mathrm{C}$ under 8 hour of natural daylight or a 24 hour photoperiod in which natural daylength was extended by the use of incandescent light. The number of days to heading of the main culm after vernalization treatment was recorded on a single plant basis for up to 100 days at the end of the experiment. Allelism test between an insensitive cultivar 'Saitama 27' and the other insensitive cultivars was also carried out in the same way.

\section{Earliness of heading in the southwestern part of Japan}

Twenty seeds of each cultivar were sown in a field at the National Agricultural Research Center for the Western Region, located at Fukuyama $\left(34^{\circ} 30^{\prime} \mathrm{N}\right.$ latitude, $133^{\circ} 21^{\prime} \mathrm{E}$ longitude) in the southwestern part of Japan, at $12 \mathrm{~cm}$ intervals with two replications, each of which being sown on November 16 in 2001 and November 18 in 2002, respectively. The date when the tip of the spikes appeared from about 50 percent of tillers was recorded as heading date. The average heading date for the two years was calculated and is presented in Table 1. Based on these data, the eight cultivars were classified into four types of earliness of heading, namely extremely early, medium, late and very late, as shown in Table 1 .

Table 1. Heading traits of eight wheat cultivars examined in the present study

\begin{tabular}{|c|c|c|c|c|c|c|c|c|c|}
\hline \multirow[b]{2}{*}{ Cultivar } & \multirow[b]{2}{*}{ Country } & \multicolumn{2}{|c|}{ Earliness of heading } & \multicolumn{4}{|c|}{ Vernalization response } & \multicolumn{2}{|c|}{ Photoperiod response } \\
\hline & & Earliness type & $\mathrm{HD}^{1)}$ & $\begin{array}{c}\text { Growth } \\
\text { habit }\end{array}$ & $V^{2)}$ & $\mathrm{NV}^{2)}$ & $V r n$ gene $^{3)}$ & Sensitivity ${ }^{4)}$ & Ppd gene ${ }^{5)}$ \\
\hline Fukuwasekomugi & Japan & extremely early & Apr 12 & spring & 9.3 & 38.5 & Vrn-D1 & insensitive & Ppd-S Ppd-F \\
\hline Norin 61 & Japan & medium & Apr 20 & spring & 10.9 & 40.3 & Vrn-D1 & insensitive & Ppd-S \\
\hline Zenkoujikomugi & Japan & medium & Apr 21 & spring & 11.4 & 39.5 & Vrn-D1 & insensitive & $P p d-S$ \\
\hline Saitama 27 & Japan & medium & Apr 22 & spring & 13.7 & 34.5 & $V r n-A 1$ & insensitive & $P p d-S$ \\
\hline Schomburgk & Australia & medium & Apr 22 & spring & 10.7 & 32.1 & $V r n-A 1$ & insensitive & $P p d-S$ \\
\hline Norin 59 & Japan & medium & Apr 22 & winter & 14.0 & 93.0 & - & insensitive & $P p d-S$ \\
\hline Norin 67 & Japan & late & Apr 26 & winter & 17.9 & 84.7 & - & insensitive & $P p d-S$ \\
\hline Haruhikari & Japan & very late & May 1 & spring & 12.8 & 34.2 & Vrn-A1 Vrn-B1 & sensitive & - \\
\hline
\end{tabular}

1) HD: Heading date in the field in Fukuyama, Japan.

2) V, NV: Number of days to heading after vernalization treatment (V) and days from sowing to heading without vernalization treatment (NV), respectively. Twenty plants were grown as described in "Materials and Methods", with two replications.

3) Vrn genotype of 'Fukuwasekomugi', 'Zenkoujikomugi' and 'Schomburgk' was identified in the present study, while that of 'Norin 61', 'Saitama 27' and 'Haruhikari' was determined by Gotoh (1979).

4) Sensitivity to short photoperiod was determined based on the results listed in Table 3 .

5) $P p d-S$ and $P p d-F$ are genes for photoperiod insensitivity tentatively designated in the present study.

- : no major Vrn or Ppd genes. 


\section{Results}

\section{Genotype for vernalization response}

Frequency distribution of the number of days to heading was unimodal with small variations in the $F_{2}$ populations vernalized for 70 days, whereas it was discontinued and bimodal without vernalization treatment except for critical crosses. Therefore, the variations observed under the latter condition were ascribed to the difference in the vernalization response of each plant. Based on the values of $F_{1}$ and the parental populations and distinct discontinuity around 65 days, $\mathrm{F}_{2}$ plants that headed within 65 days were classified into the spring type and those that headed after 66 days into the winter type. It was reconfirmed that the four tester lines, 'Saitama 27', 'TD(B)', 'TD(E)', and 'TD(F)', harboured a different single $V r n$ gene (Table 2). Segregation of spring and winter types in the $F_{2}$ populations of the crosses between a winter cultivar 'Norin 59' and three cultivars, 'Fukuwasekomugi', 'Zenkoujikomugi' and 'Schomburgk', fitted to the expected ratio of $3: 1$, showing that these three cultivars harboured a single $V r n$ gene (Table 2). $\mathrm{F}_{2}$ populations of 'Fukuwasekomugi' $\times$ 'TD $(E)$ ', 'Zenkoujikomugi' $\times$
'TD(E)' and 'Schomburgk' × 'Saitama 27' failed to segregate into the winter type, while segregation into spring and winter types fitted to the expected ratio of $15: 1$ in other cross combinations (Table 2). Therefore, three cultivars, 'Fukuwasekomugi', 'Zenkoujikomugi' and 'Schomburgk', were found to carry $V r n-D 1, V r n-D 1$ and $V r n-A 1$, respectively.

Characteristics of the $V r n$ genotype of the eight cultivars are presented in Table 1. Since the genotype of five wheat cultivars with medium heading was classified into $V r n-A 1$ type, $V r n-D 1$ type and winter genotype, it appeared that earliness of heading was independent of the Vrn genotype in the southwestern part of Japan.

\section{Photoperiod response}

The variations in the number of days to heading under a 24 hour photoperiod after vernalization treatment were small (18.0-27.0 days) among the eight wheat cultivars, whereas those under a 8 hour photoperiod were very large (25.6-80.4 days), as shown in Table 3. Therefore, the number of days to heading under the 8 hour photoperiod indicated the degree of sensitivity to short photoperiod. The cultivar 'Haruhikari' was highly sensitive to short photoperiod

Table 2. Segregation of spring and winter types in $F_{2}$ population of the crosses between tester lines and between three cultivars and tester lines

\begin{tabular}{|c|c|c|c|c|c|c|c|c|c|}
\hline \multirow[b]{2}{*}{ Cross combination } & \multicolumn{3}{|c|}{ No. of plants } & \multicolumn{6}{|c|}{$\chi^{2}$ for the expected ratio } \\
\hline & $\begin{array}{l}\text { Spring } \\
\text { type }\end{array}$ & $\begin{array}{c}\text { Winter } \\
\text { type }\end{array}$ & Total & $3: 1$ & & $15: 1$ & & $63: 1$ & \\
\hline Norin $59 \times$ Saitama 27 & 99 & 31 & 130 & 0.09 & & 68.70 & $* *$ & 419.70 & $* *$ \\
\hline Norin $59 \times \mathrm{TD}(\mathrm{B})$ & 99 & 31 & 130 & 0.09 & & 68.70 & $* *$ & 419.70 & $* *$ \\
\hline Norin $59 \times \mathrm{TD}(\mathrm{E})$ & 96 & 34 & 130 & 0.09 & & 87.90 & $* *$ & 511.13 & $* *$ \\
\hline Norin $59 \times \mathrm{TD}(\mathrm{F})$ & 98 & 32 & 130 & 0.01 & & 74.83 & $* *$ & 449.17 & $* *$ \\
\hline Saitama $27 \times \mathrm{TD}(\mathrm{B})$ & 119 & 11 & 130 & 18.96 & $* *$ & 1.09 & & 40.23 & $* *$ \\
\hline Saitama $27 \times \mathrm{TD}(\mathrm{E})$ & 121 & 9 & 130 & 22.66 & $* *$ & 0.10 & & 24.29 & $* *$ \\
\hline Saitama $27 \times \mathrm{TD}(\mathrm{F})$ & 123 & 7 & 130 & 26.68 & $* *$ & 0.17 & & 12.35 & $* *$ \\
\hline $\mathrm{TD}(\mathrm{B}) \times \mathrm{TD}(\mathrm{E})$ & 122 & 8 & 130 & 24.63 & $* *$ & 0.00 & & 17.82 & $* *$ \\
\hline $\mathrm{TD}(\mathrm{B}) \times \mathrm{TD}(\mathrm{F})$ & 123 & 7 & 130 & 26.68 & $* *$ & 0.17 & & 12.35 & $* *$ \\
\hline $\mathrm{TD}(\mathrm{E}) \times \mathrm{TD}(\mathrm{F})$ & 125 & 5 & 130 & 31.03 & $* *$ & 1.28 & & 4.41 & $*$ \\
\hline Fukuwasekomugi $\times$ Saitama 27 & 124 & 6 & 130 & 28.81 & $* *$ & 0.59 & & 7.88 & $* *$ \\
\hline Fukuwasekomugi $\times \mathrm{TD}(\mathrm{B})$ & 117 & 13 & 130 & 15.60 & $* *$ & 3.12 & & 60.17 & $* *$ \\
\hline Fukuwasekomugi $\times \mathrm{TD}(\mathrm{E})$ & 130 & 0 & 130 & 43.33 & $* *$ & 8.67 & $* *$ & 2.06 & \\
\hline Fukuwasekomugi $\times \mathrm{TD}(\mathrm{F})$ & 123 & 7 & 130 & 26.68 & $* *$ & 0.17 & & 12.35 & $* *$ \\
\hline Fukuwasekomugi $\times$ Norin 59 & 95 & 35 & 130 & 0.26 & & 94.82 & $* *$ & 543.60 & $* *$ \\
\hline Zenkoujikomugi ×Saitama 27 & 120 & 10 & 130 & 20.77 & $* *$ & 0.46 & & 31.76 & $* *$ \\
\hline Zenkoujikomugi ×TD(B) & 122 & 8 & 130 & 24.63 & $* *$ & 0.00 & & 17.82 & $* *$ \\
\hline Zenkoujikomugi $\times \mathrm{TD}(\mathrm{E})$ & 130 & 0 & 130 & 43.33 & $* *$ & 8.67 & $* *$ & 2.06 & \\
\hline Zenkoujikomugi×TD(F) & 123 & 7 & 130 & 26.68 & $* *$ & 0.17 & & 12.35 & $* *$ \\
\hline Zenkoujikomugi $\times$ Norin 59 & 103 & 27 & 130 & 1.24 & & 46.77 & $* *$ & 311.80 & $* *$ \\
\hline Schomburgk $\times$ Saitama 27 & 130 & 0 & 130 & 43.33 & $* *$ & 8.67 & $* *$ & 2.06 & \\
\hline Schomburgk $\times$ TD(B) & 121 & 9 & 130 & 22.66 & $* *$ & 0.10 & & 24.29 & $* *$ \\
\hline Schomburgk $\times \mathrm{TD}(\mathrm{E})$ & 123 & 7 & 130 & 26.68 & $* *$ & 0.17 & & 12.35 & $* *$ \\
\hline Schomburgk $\times \mathrm{TD}(\mathrm{F})$ & 122 & 8 & 130 & 24.63 & $* *$ & 0.00 & & 17.82 & $* *$ \\
\hline Schomburgk $\times$ Norin 59 & 99 & 31 & 130 & 0.09 & & 68.70 & $* *$ & 419.70 & $* *$ \\
\hline
\end{tabular}

\footnotetext{
*** Significant at the $5 \%$ and $1 \%$ levels, respectively.
} 
and therefore did not carry any gene for photoperiod insensitivity, while the other cultivars were slightly sensitive or insensitive, 'Fukuwasekomugi' being most insensitive. We therefore assumed that seven cultivars other than 'Haruhikari' must harbour major gene(s) for photoperiod insensitivity. The $\mathrm{F}_{1}$ hybrids of the crosses between 'Haruhikari' and the insensitive cultivars headed earlier, under the 8 hour photoperiod, by 8.0 to 17.8 days than their respective midparent value (Table 3 ), indicating that insensitivity was incompletely dominant over sensitivity.

\section{Genotype for photoperiod response}

As shown in Fig. 1A-B, Fig. 2A-E and Fig. 3A,C, the frequency distribution of the number of days to heading in the $F_{2}$ and $B_{1} F_{1}$ populations of crosses between a sensitive cultivar 'Haruhikari' and insensitive cultivars was unimodal with small variations under a 24 hour photoperiod (open bar), while those observed under a 8 hour photoperiod were discontinued and bimodal (solid bar). The variations observed under the 8 hour photoperiod were therefore due to the difference in sensitivity to short photoperiod. Based on the number of days to heading of the $F_{1}$ and the parental populations (Table 3 ) and the distinct discontinuity around 65 days (Fig. 1A-B, Fig. 2A-E and Fig. 3A,C), the $F_{2}$ and $\mathrm{B}_{1} \mathrm{~F}_{1}$ plants that headed within 65 days were classified into photoperiod-insensitive and those that did not head by 66 days were classified into sensitive. Six cultivars insensitive to short photoperiod, 'Saitama 27', 'Norin 61', 'Zenkoujikomugi', 'Schomburgk', 'Norin 59' and 'Norin 67', were found to harbour a single dominant gene, since the segregation of the insensitive and sensitive types in the $\mathrm{F}_{2}$ and $\mathrm{B}_{1} \mathrm{~F}_{1}$ populations fitted to the expected ratios of $3: 1$ and $1: 1$, respectively (Table 4, Fig. 1A-B and Fig. 2A-E). In addition, allelism test between six insensitive cultivars (Table 4 and Fig. 2F-J) showed that the gene for photoperiod insensitivity of these cultivars was allelic to each other. We tentatively designated this gene as Ppd-S. Table 4 and Fig. 3A,C also showed that the photoperiod insensitivity of the most insensitive cultivar 'Fukuwasekomugi' was controlled by two dominant genes. Although the size of the $F_{2}$ population of 'Saitama 27' $\times$ 'Fukuwasekomugi' was not large enough (Table 4), no transgressive segregants headed later than 'Saitama 27' (Fig. 3B). Therefore, it was suggested that 'Fukuwasekomugi' carried $P p d-S$ in common with 'Saitama 27 ', and the other gene carried by 'Fukuwasekomugi' was tentatively designated as $P p d-F$.

The $P p d$ genes carried by the eight cultivars are listed in Table 1 . The Ppd genotypes of the extremely early heading type, the medium to late heading types, and the very late heading type were $P p d-S P p d-F, P p d-S p p d-F$, and $p p d-S$ $p p d-F$, respectively, indicating that earliness of heading was closely related to the Ppd genotype of wheat cultivars in the southwestern part of Japan.

\section{Discussion}

Gotoh (1979) and Iwaki et al. (2000) reported that wheat cultivars indigenous to Japan carried $V r n-D 1$ as a single Vrn gene, and suggested that cultivars with Vrn-D1 were more adaptable to the growing conditions in the southern part of Japan than those with Vrn-A1, which are susceptible to frost damage. The present study also showed that the two Japanese wheat cultivars, 'Fukuwasekomugi' and 'Zenkoujikomugi', developed in the southern part of Japan, carried Vrn-D1 (Table 2). According to Kato and Yamagata (1988), wheat cultivars with $V r n-A 1$ are completely insensitive to vernalization and those with $V r n-D 1$ are slightly sensitive. These facts strongly support the concept of Gotoh (1979) and Iwaki et al. (2000), according to which partial requirement of vernalization by $V r n-D 1$ is important for

Table 3. Number of days to heading of parental and $F_{1}$ populations under 24 hour or 8 hour photoperiod after vernalization treatment

\begin{tabular}{|c|c|c|c|c|c|c|c|c|}
\hline \multirow[t]{2}{*}{ Parent and cross combination } & \multirow[t]{2}{*}{ Generation } & \multicolumn{3}{|c|}{$\begin{array}{l}\text { Days to heading } \\
\text { under } 24 \text { hour photoperiod }\end{array}$} & \multicolumn{3}{|c|}{$\begin{array}{l}\text { Days to heading } \\
\text { under } 8 \text { hour photoperiod }\end{array}$} & \multirow{2}{*}{$\begin{array}{l}\text { Difference } \\
\text { (B) }-(\mathrm{A})\end{array}$} \\
\hline & & Plant & Range & Mean (A) & Plant & Range & Mean (B) & \\
\hline Haruhikari & $\mathrm{P}$ & 5 & $25-28$ & 27.0 & 5 & $71-87$ & 80.4 & 53.4 \\
\hline Saitama 27 & $\mathrm{P}$ & 5 & $24-25$ & 24.6 & 5 & $36-41$ & 38.4 & 13.8 \\
\hline Norin 61 & $\mathrm{P}$ & 5 & $22-24$ & 22.6 & 5 & $35-39$ & 37.6 & 15.0 \\
\hline Zenkoujikomugi & $\mathrm{P}$ & 5 & $19-21$ & 20.2 & 5 & $33-36$ & 33.8 & 13.6 \\
\hline Schomburgk & $\mathrm{P}$ & 5 & $24-25$ & 24.2 & 5 & $36-40$ & 38.6 & 14.4 \\
\hline Norin 59 & $\mathrm{P}$ & 5 & $20-22$ & 21.0 & 5 & $41-42$ & 41.6 & 20.6 \\
\hline Norin 67 & $\mathrm{P}$ & 5 & $24-25$ & 24.8 & 5 & $39-43$ & 40.0 & 15.3 \\
\hline Fukuwasekomugi & $\mathrm{P}$ & 5 & 18 & 18.0 & 5 & $25-26$ & 25.6 & 7.6 \\
\hline Haruhikari×Saitama 27 & $\mathrm{~F}_{1}$ & 5 & $27-28$ & 27.6 & 5 & $48-52$ & 49.8 & 22.2 \\
\hline Haruhikari $\times$ Norin 61 & $\mathrm{~F}_{1}$ & 5 & $24-26$ & 25.2 & 5 & $50-53$ & 51.0 & 25.8 \\
\hline Haruhikari×Zenkoujikomugi & $\mathrm{F}_{1}$ & 5 & $24-25$ & 24.4 & 5 & $45-53$ & 48.0 & 23.6 \\
\hline Haruhikari $\times$ Schomburgk & $\mathrm{F}_{1}$ & 5 & $27-28$ & 27.2 & 5 & $50-52$ & 50.6 & 23.4 \\
\hline Haruhikari $\times$ Norin 59 & $\mathrm{~F}_{1}$ & 5 & $25-26$ & 25.2 & 5 & $47-50$ & 48.0 & 22.8 \\
\hline Haruhikari $\times$ Norin 67 & $\mathrm{~F}_{1}$ & 5 & $25-27$ & 26.0 & 5 & $50-52$ & 51.0 & 25.0 \\
\hline Haruhikari $\times$ Fukuwasekomugi & $\mathrm{F}_{1}$ & 5 & $22-23$ & 22.6 & 5 & $33-37$ & 35.2 & 12.6 \\
\hline
\end{tabular}


Table 4. Segregation of photoperiod response in $\mathrm{F}_{2}$ and $\mathrm{B}_{1} \mathrm{~F}_{1}$ populations

\begin{tabular}{|c|c|c|c|c|c|c|c|}
\hline \multirow{2}{*}{$\begin{array}{l}\text { Cross combination } \\
\left.\text { ( } \mathrm{F}_{2} \text { populations }\right)\end{array}$} & \multicolumn{2}{|c|}{$\begin{array}{l}\text { Segregation of sensitivity to } \\
\text { short photoperiod }\end{array}$} & \multirow[t]{2}{*}{ Total } & \multicolumn{4}{|c|}{$\chi^{2}$ for the expected ratio } \\
\hline & Insensitive & Sensitive & & $3: 1$ & & $15: 1$ & $63: 1$ \\
\hline Haruhikari ×Saitama 27 & 104 & 26 & 130 & 1.73 & & $41.95 * *$ & $287.32 * *$ \\
\hline Haruhikari $\times$ Norin 61 & 96 & 34 & 130 & 0.09 & & $87.90 * *$ & $511.13 * *$ \\
\hline Haruhikari $\times$ Zenkoujikomugi & 96 & 34 & 130 & 0.09 & & $87.90 * *$ & $511.13 * *$ \\
\hline Haruhikari $\times$ Schomburgk & 94 & 36 & 130 & 0.50 & & $102.01 * *$ & $577.08 * *$ \\
\hline Haruhikari $\times$ Norin 59 & 107 & 23 & 130 & 3.70 & & $29.05 * *$ & $219.90 * *$ \\
\hline Haruhikari $\times$ Norin 67 & 96 & 34 & 130 & 0.09 & & $87.90 * *$ & $511.13 * *$ \\
\hline Haruhikari $\times$ Fukuwasekomugi & 126 & 4 & 130 & $33.32 *$ & $* *$ & 2.23 & 1.94 \\
\hline Saitama $27 \times$ Norin 61 & 130 & 0 & 130 & $43.33 *$ & $* *$ & $8.67 * *$ & 2.06 \\
\hline Saitama $27 \times$ Zenkoujikomugi & 130 & 0 & 130 & $43.33 *$ & ** & $8.67 * *$ & 2.06 \\
\hline Saitama $27 \times$ Schomburgk & 130 & 0 & 130 & $43.33 *$ & $* *$ & $8.67 * *$ & 2.06 \\
\hline Saitama $27 \times$ Norin 59 & 130 & 0 & 130 & $43.33 *$ & $* *$ & $8.67 * *$ & 2.06 \\
\hline Saitama $27 \times$ Norin 67 & 130 & 0 & 130 & $43.33 *$ & $* *$ & $8.67 * *$ & 2.06 \\
\hline Saitama $27 \times$ Fukuwasekomugi & 130 & 0 & 130 & $43.33 *$ & $* *$ & $8.67 * *$ & 2.06 \\
\hline \multirow{2}{*}{$\begin{array}{l}\text { Cross combination } \\
\left(\mathrm{B}_{1} \mathrm{~F}_{1} \text { populations }\right)\end{array}$} & \multicolumn{2}{|c|}{$\begin{array}{l}\text { Segregation of sensitivity to } \\
\text { short photoperiod }\end{array}$} & \multirow[t]{2}{*}{ Total } & \multicolumn{4}{|c|}{$\chi^{2}$ for the expected ratio } \\
\hline & Insensitive & Sensitive & & $1: 1$ & & $3: 1$ & $7: 1$ \\
\hline $\begin{array}{l}\text { Haruhikari } \times \\
\text { (Haruhikari } \times \text { Saitama 27) }\end{array}$ & 26 & 29 & 55 & 0.16 & & $22.55 * *$ & $81.37 * *$ \\
\hline $\begin{array}{l}\text { Haruhikari } \times \\
\text { (Haruhikari } \times \text { Fukuwasekomugi) }\end{array}$ & 87 & 37 & 124 & $20.16 *$ & $* *$ & 1.55 & $34.08 * *$ \\
\hline
\end{tabular}

** Significant at the $1 \%$ level.

adaptation in the southern part of Japan.

It was suggested that 'Fukuwasekomugi' carried $P p d-F$ in addition to $P p d-S$ commonly carried by the other insensitive cultivars. In the backcross population of 'Haruhikari' $\times$ ('Haruhikari' $\times$ 'Fukuwasekomugi'), $\mathrm{B}_{1} \mathrm{~F}_{1}$ segregants insensitive to short photoperiod showed an almost trimodal distribution when classified at two-day intervals (Fig. 3C). This segregation pattern appeared to fit to the $1: 1: 1$ ratio expected, if 'Fukuwasekomugi' had two genes which showed different degrees of insensitivity and additive interaction. The number of days to heading of the $F_{1}$ plants of crosses between 'Haruhikari' and six cultivars carrying $P p d-S$ (Table 3) was relatively uniform (48.0-51.0 days), while 'Haruhikari' $\times$ 'Fukuwasekomugi' headed earlier (35.2 days) (Table 3). From these results, it is reasonable to assume that the above three modes from early to late heading corresponded to the Ppd-S ppd-S Ppd-F ppd-F, ppd-S ppd-S Ppd$F p p d-F$ and $P p d-S$ ppd-S ppd-F ppd-F genotypes, respectively. Therefore it is likely that the effect of $P p d-F$ is probably stronger than that of $P p d-S$. It was considered that $P p d-$ $S$ and $P p d-F$ display an additive effect to increase insensitivity and consequently, that 'Fukuwasekomugi' is highly insensitive to short photoperiod, as shown in Table 3.

Photoperiod response is an important physiological factor controlling the earliness of heading in the southwestern part of Japan (Hashimoto and Hirano 1963, Yasuda and Shimoyama 1965, Gotoh 1977, Yoshida et al. 1983). Nevertheless, the effect of the genes for the photoperiod response on the earliness of heading in the southwestern part of Japan has not been investigated. The present study showed that the very
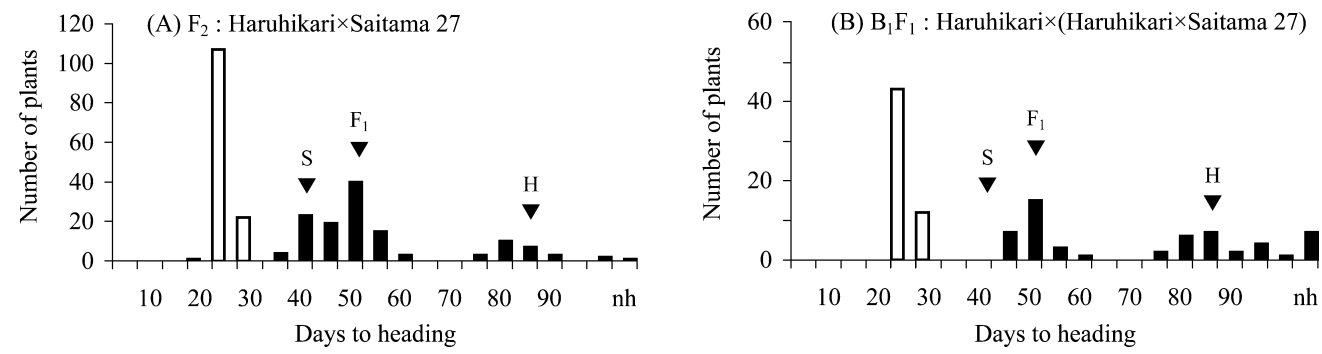

Fig. 1. Frequency distribution of the number of days to heading of $\mathrm{F}_{2}$ and $\mathrm{B}_{1} \mathrm{~F}_{1}$ populations in the cross between 'Haruhikari' and 'Saitama 27' under 24 hour (open bar) or 8 hour (solid bar) photoperiod after vernalization treatment. nh: Plants did not head within 100 days. $\boldsymbol{\nabla}$ : Number of days to heading of parents and $F_{1}$ under 8 hour photoperiod. Parents were indicated by their initial letter. 

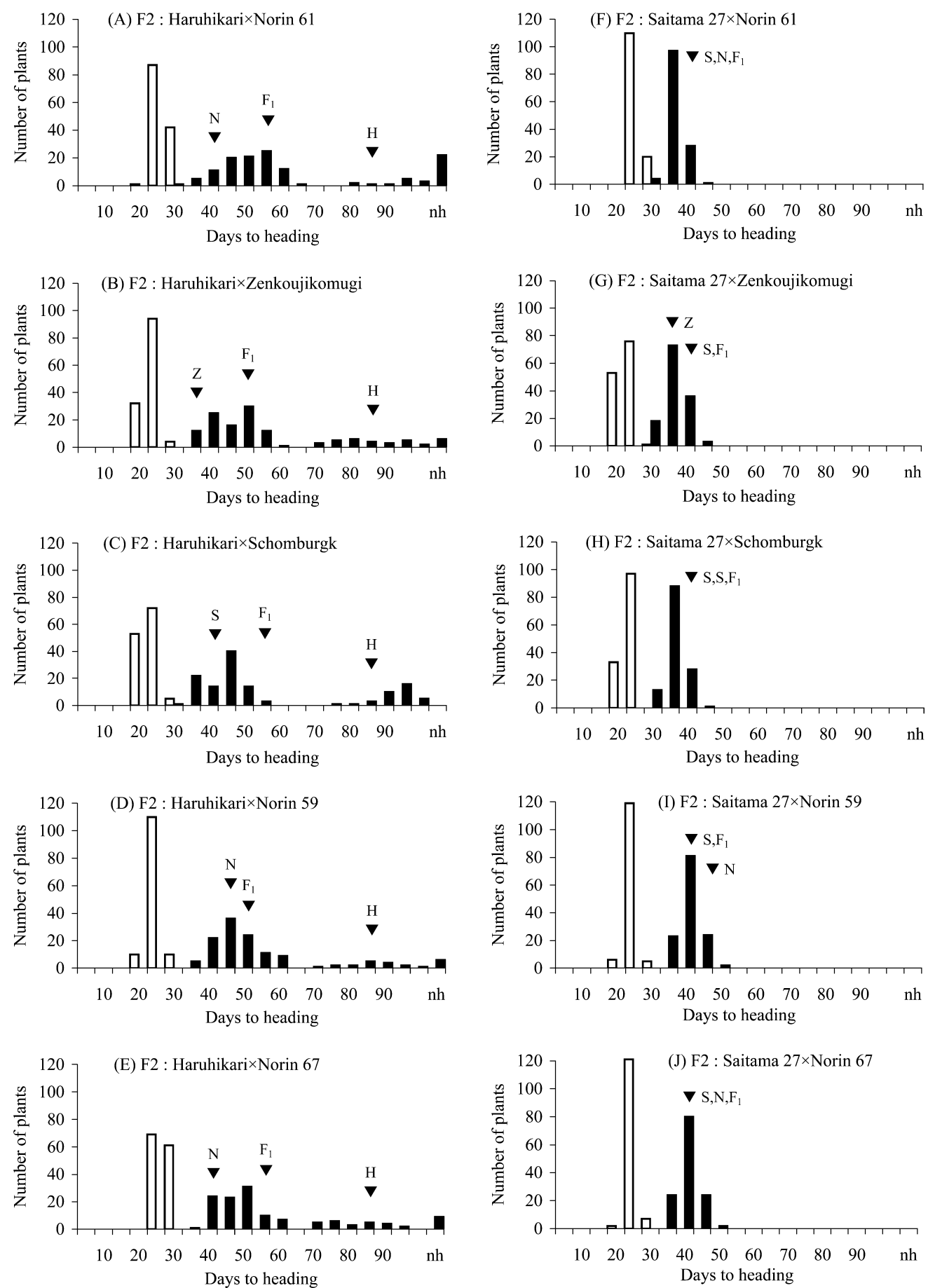

Fig. 2. Frequency distribution of the number of days to heading of $F_{2}$ populations in crosses between two cultivars, 'Haruhikari' and 'Saitama 27', and five cultivars, 'Norin 61', 'Zenkoujikomugi', 'Schomburgk', 'Norin 59' and 'Norin 67', under 24 hour (open bar) or 8 hour (solid bar) photoperiod after vernalization treatment. nh: Plants did not head within 100 days. $\nabla$ : Number of days to heading of parents and $F_{1}$ under 8 hour photoperiod. Parents were indicated by their initial letter.

late heading cultivar 'Haruhikari' did not carry major genes for insensitivity to photoperiod. On the other hand, six medium to late heading cultivars, 'Norin 61 ', 'Zenkoujikomugi', 'Saitama 27', 'Schomburgk', 'Norin 59' and 'Norin 67', carried a single and common gene $P p d-S$ for insensitivity, while the extremely early heading cultivar 'Fukuwasekomugi' carried two genes for insensitivity (Table 4). These results clearly indicated that the earliness of wheat cultivars in the southwestern part of Japan is strongly related to the Ppd genotype, but is independent of the Vrn genotype. 

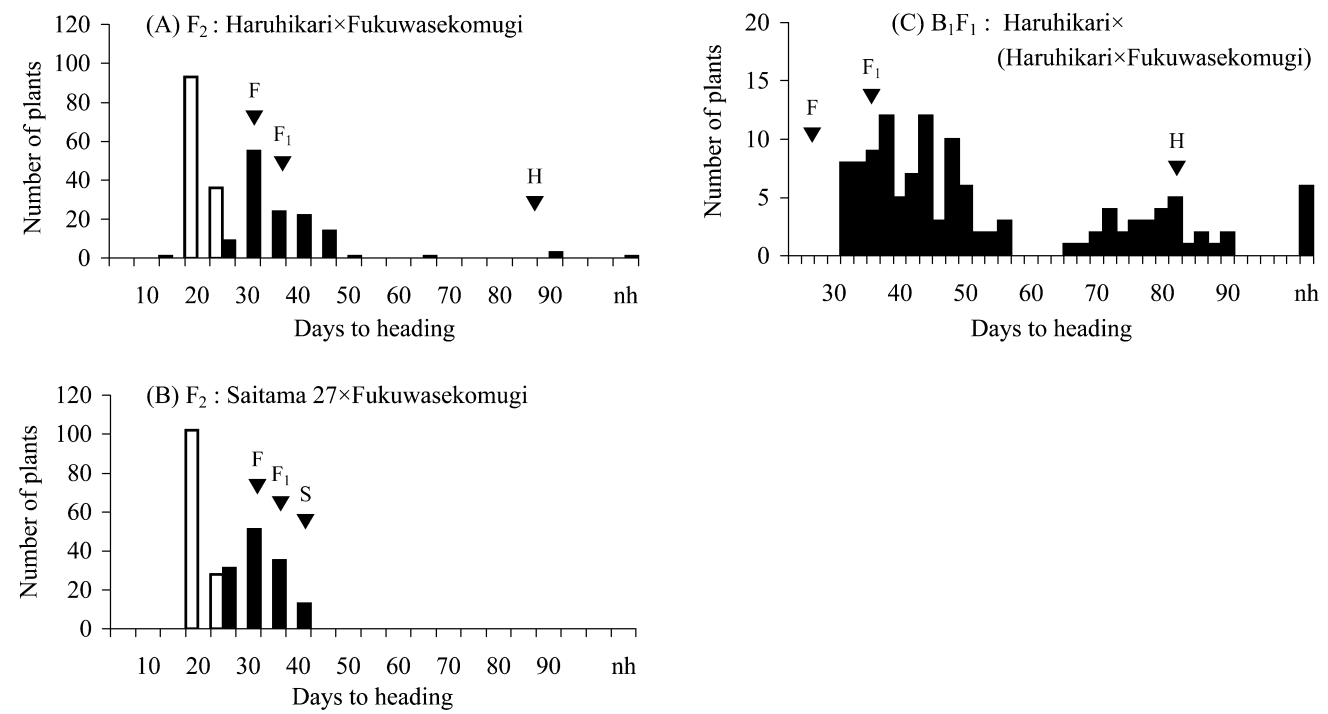

Fig. 3. Frequency distribution of the number of days to heading of $F_{2}$ and $B_{1} F_{1}$ populations in crosses between two cultivars, 'Haruhikari' and 'Saitama 27', and a cultivar 'Fukuwasekomugi' under 24 hour (open bar) or 8 hour (solid bar) photoperiod after vernalization treatment. nh: Plants did not head within 100 days. $\boldsymbol{\nabla}$ : Number of days to heading of parents and $F_{1}$ under 8 hour photoperiod. Parents were indicated by their initial letter.

Therefore, the Ppd genes are undoubtedly very important for regulating the heading time of wheat in the southwestern part of Japan.

Since the photoperiod response is a quantitative trait, the genotype can not be identified without segregation analysis under short daylength. Therefore, marker-assisted selection is indispensable for introducing Ppd genes in a breeding programme. In barley, STS markers closely linked to Ppd-H1 (0.6-0.8 cM) have been developed by AFLP analysis (Decousset et al. 2000), and can be utilized as selection markers, while in wheat, Ppd genes have been mapped by using RFLP markers (Gale et al. 1995, Shindo et al. 2003) which are usually less polymorphic among wheat cultivars. Recently, Hanocq et al. (2005) have succeeded in locating Ppd-B1 and Ppd-D1 on the SSR map. However, the linkage between the Ppd genes and SSR markers was not close enough to utilize them as selection markers. Therefore, further studies should be conducted to develop closely linked markers. By using these markers, it will be possible to determine which genes among $P p d-A 1, P p d-B 1$ and $P p d-D 1$ corresponded to the two genes, $P p d-S$ and $P p d-F$, tentatively designated in the present study. Near-isogenic lines for the photoperiod response can be established also by using these markers, and may enable to clarify the effects of the Ppd genes on the earliness of heading in the southwestern part of Japan as well as their pleiotropic effects on culm length and other agronomic traits.

\section{Acknowledgements}

We thank Mrs. M.Kyan, Mrs. N.Makiya, Mrs. R.Tohyama, Mr. M.Shimajiri, Mr. J.Sawase and Mr.
M.Yoshida, Okinawa Subtropical Station, JIRCAS for their technical assistance. We are also grateful to the National Institute of Agrobiological Sciences and the Laboratory of Wheat and Barley Breeding of the National Agricultural Research Center for the Tohoku Region for providing the seeds used in the present study. This study was supported by a Grant-in-Aid for research programs of wheat and barley production from the Ministry of Agriculture, Forestry and Fisheries of Japan.

\section{Literature Cited}

Decousset,L., S.Griffiths, R.P.Dunford, N.Pratchett and D.A.Laurie (2000) Development of STS markers closely linked to the PpdH1 photoperiod response gene of barley (Hordeum vulgare L.). Theor. Appl. Genet. 101: 1202-1206.

Fujita,M., Y.Taniguchi, K.Ujihara and A.Sasaki (1995) Ear primordia development and stem elongation of near-isogenic lines for vernalization requirement in extremely-early maturing wheat cultivars (Triticum aestivum L.). Breed. Sci. 45: 97-104 (in Japanese with English summary).

Gale,M.D., M.D.Atkinson, C.N.Chinoy, R.L.Harcourt, J.Jia, Q.Y.Li and K.M.Devos (1995) Genetic maps of hexaploid wheat. Proc. $8^{\text {th }}$ Inter. Wheat Genet. Symp., Beijing, China. p. 29-40.

Gotoh,T. (1977) Varietal differences in photoperiodic and thermal responses of wheat. Jpn. J. Breed. 27: 57-69 (in Japanese with English summary).

Gotoh,T. (1979) Genetic studies on growth habit of some important spring wheat cultivars in Japan, with special reference to the identification of the spring genes involved. Jpn. J. Breed. 29: 133-145.

Hanocq,E., M.Niarquin, E.Heumez, M.Rousset and J.LeGouis (2004) Detection and mapping of QTL for earliness components in a bread wheat recombinant inbred lines population. Theor. Appl. 
Genet. 110: 106-115.

Hashimoto, R. and J.Hirano (1963) Selection of parental materials for crosses in the early-maturity breeding program of wheat. (Part 3) Genetic studies on maturing date in $F_{2}-F_{5}$ generations. Bull.Chugoku Natl. Agric. Exp. Stn. 9: 31-61 (in Japanese with English summary).

Iwaki,K., K.Nakagawa, H.Kuno and K.Kato (2000) Ecogeographical differentiation in east Asian wheat, revealed from the geographical variation of growth habit and $V r n$ genotype. Euphytica 111: 137-143.

Iwaki,K., J.Nishida, T. Yanagisawa, H. Yoshida and K. Kato (2002) Genetic analysis of $V r n-B 1$ for vernalization requirement by using linked dCAPS markers in bread wheat (Triticum aestivum L.). Theor. Appl. Genet. 104: 571-576.

Kato,K. and H.Yamagata (1988) Method for evaluation of chilling requirement and narrow-sense earliness of wheat cultivars. Jpn. J. Breed. 38: 172-186.

Kato,K. and S.Yamashita (1991) Varietal variation in photoperiodic response, chilling requirement and narrow-sense earliness and their relation to heading time in wheat (Triticum aestivum L.). Jpn. J. Breed. 41: 475-484.

Kato, K., K.Nakagawa and H.Kuno (1993) Chromosome location of the genes for vernalization response, $\mathrm{Vrn} 2$ and $\mathrm{Vrn} 4$, in common wheat, Triticum aestivum L.. Wheat Information Service 76: 53 .

Kato,K., M.Yamashita, K.Ishimoto, H.Yoshida and M.Fujita (2003) Genetic analysis of two genes for vernalization response, the former Vrn2 and Vrn4, by using PCR based molecular markers. Proc. $10^{\text {th }}$ Int. Wheat Genet. Symp., Rome, Italy. p. 971-973.

Keim,D.L., J.R.Welsh and R.L.Mcconnell (1973) Inheritance of photoperiodic heading response in winter and spring cultivars of bread wheat. Can. J. Plant Sci. 53: 247-250.

Law, C.N., A.J.Worland and B.Giorgi (1976) The genetic control of ear-emergence time by chromosomes $5 \mathrm{~A}$ and $5 \mathrm{D}$ of wheat.
Heredity 36: 49-58.

Pirasteh,B. and J.R.Welsh (1975) Monosomic analysis of photoperiod response in wheat. Crop Sci. 15: 503-505.

Pugsley,A.T. (1972) Additional genes inhibiting winter habit in wheat. Euphytica 21: 547-552.

Scarth,R. and C.N.Law (1983) The location of the photoperiod gene, $P p d 2$ and an additional genetic factor for ear-emergence time on chromosome 2B of wheat. Heredity 51: 607-619.

Scarth,R. and C.N.Law (1984) The control of the day-length responses in wheat by the group 2 chromosomes. Z.Pflanzenzuchtg 92: $140-150$.

Shindo,C., H.Tsujimoto and T. Sasakuma (2003) Segregation analysis of heading traits in hexaploid wheat utilizing recombinant inbred lines. Heredity 90: 56-63.

Snape,J.W., K.Butterworth, E.Whitechurch and A.J.Worland (2001) Waiting for fine times: genetics of flowering time in wheat. Euphytica 119: 185-190.

Sourdille,P., J.W.Snape, T.Cadalen, G.Charmet, N.Nakata, S.Bernard and M.Bernard (2000) Detection of QTLs for heading time and photoperiod response in wheat using a doubled-haploid population. Genome 43: 487-494.

Taya,S., T.Tohnooka, M. Seki, M.Taira, T.Tsutsumi, K. Ujihara, A.Sasaki, R.Yoshikawa, M.Fujita, Y.Taniguchi and T.Ban (2003) New wheat cultivar "Iwainodaichi". Bull. Natl. Agric. Res. Cent. Kyushu Okinawa Reg. 42: 1-17 (in Japanese).

Welsh,J.R., D.L.Keim, B.Pirasteh and R.D.Richards (1973) Genetic control of photoperiod response in wheat. Proc. $4^{\text {th }}$ Int. Wheat Genet. Symp., Columbia, USA. p. 879-884.

Yasuda,S. and H.Shimoyama (1965) Analysis of internal factors influencing the heading time of wheat varieties. Ber. Ohara Inst. landw. Biol. Okayama U. 13: 23-38.

Yoshida,H., M.Kamio and K.Kawaguchi (1983) Evaluation of cultivars for early matureness in the Japanese wheat breeding. Proc. $6^{\text {th }}$ Int. Wheat Genet. Symp., Kyoto, Japan. p. 601-612. 